\title{
Modulation of heat shock protein immunolocalization in cerebral cortex by melatonin therapy in heat stressed rats
}

Hala Elwy Hashem ${ }^{1 *}$ and Abeer Abdalla Fikry ${ }^{2}$

*Correspondence: halaelwy@zu.edu.eg

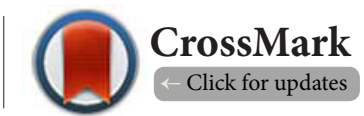

${ }^{1}$ Histology and Cell Biology Department, Faculty of Medicine, Zagazig University, Egypt. ${ }^{2}$ Clinical Pathology Department, Faculty of Medicine, Zagazig University, Egypt.

\begin{abstract}
Heat stress leads clinically to manifestations of central nervous system dysfunction. Heat shock proteins (HSPs) function as molecular chaperones protecting the cells from damage. Melatonin has therapeutic and prophylactic effects on heatstroke-induced multiple organ dysfunction. The present work aimed to investigate the protective effect of melatonin against heat stress-induced histological and HSP60 immunoexpression alterations of cerebral cortex in adult male albino rats. Forty adult male albino rats were used and divided into three groups; I (control) II (3 days heat stressed) and III ( 3 days heat stressed with melatonin treatment). Cerebral cortex specimens were processed to prepare sections for light microscope examination and blood samples were obtained for oxidative stress and antioxidant analysis. Hematoxylin and eosin stained sections showed degenerative changes in cerebral cortex of rats exposed to heat for 3 days in the form of apoptotic neurons and swelling of astrocytes processes. Neuropil edema, subarachnoid hemorrhage and congested blood vessels were also observed with accompanied increase in serum oxidative stress markers and decrease in antioxidant marker. Melatonin treatment with heat stress showed more preserved nervous tissue with accompanied increase in serum antioxidant marker. HSP60 immunoexpression was weak cytoplasmic in control group which significantly increased and became strong cytoplasmic after 3 days of heat exposure. With melatonin treatment with heat stress nuclear, HSP60 immunoexpression was moderate nuclear in some neurons and strong cyoplasmic in others. In conclusion, melatonin ameliorates heat exposure induced degenerative changes in cerebral cortex of adult male albino rats most probably through antioxidant effect with modulation in HSP60 immunoexpression pattern. Hence, more attention should be thrown to melatonin as a protective treatment to avoid heat stress degenerative effect on cerebral cortex.
\end{abstract}

Keywords: Microscope, Albino rat, HSP60, Melatonin

\section{Introduction}

Temperature has important drawbacks on body fitness and the adaptation to global warming and to the changes in thermal environments is important [1]. In the tropical climate zone, increasing temperatures affecting developing countries disproportionately because it reduces work productivity and hence economic productivity could be diminished [2].

Heat stroke is a life-threatening illness that is characterized clinically by manifestations of central nervous system dysfunction such as delirium, seizures or coma. The most effective therapy is the rapid body cooling and supporting the function of several organs. However, despite these efforts, many patients exposed to permanent neurological disorders, thermoregulatory dysfunction or even death [3]. Heat cytotoxic effect and the systemic inflammatory led to multiple organs damage and heat stroke is better to be prevented than to be treated [4]. Heat stress was reported to disrupt specific and non-specific immune responses in intestinal tract of pigs with barrier disruption [5]. Food consumption and gaining body weight were observed to be decreased after a daily mice exposure to $38.5^{\circ} \mathrm{C}$ for $60 \mathrm{~min}$ for 2 weeks. Also, the levels of corticosterone and vasopressin in the blood, and catecholamine and serotonin metabolite in the hypothalamus increased when mice exposed to above $37^{\circ} \mathrm{C}$ for 60 minutes [6]. Previous investigators suggested that

() 2018 Hashem et al; licensee Herbert Publications Ltd. This is an Open Access article distributed under the terms of Creative Commons Attribution License (http://creativecommons.org/licenses/by/3.0). This permits unrestricted use, distribution, and reproduction in any medium, provided the original work is properly cited. 
heat stress led to deactivation of autophagy and suppressed autophagosomal degradation that led to accumulation of damaged mitochondria in muscle cells with formation of abnormal cytoplasmic environment [7].

In the cell, the proteins to fulfill their biological functions must be folded as an essential process which is aided by molecular chaperones [8]. Heat shock proteins (HSPs) are the major molecular chaperones whose function is to mediate the proper folding of cell proteins under normal conditions and to maintain their native conformations during stress conditions and also help in refolding of proteins that denatured due to stress $[9,10]$. Under normal conditions, HSP levels in the cell able to mediate proper folding and match the protein synthesis. However, under cellular stress, synthesized proteins unfold and exceed the capacity of cellular chaperones to prevent protein aggregation leading to loss of protein homeostasis and proteotoxicity [11]. Moreover, HSPs are required for trafficking of protein to its target organelles and to facilitate transfer of misfolded proteins to proteasome for degradation and have role during vertebrate neurogenesis $[\mathbf{9 , 1 2}]$. In addition, HSPs are essential to buffer mutations that may disrupt protein's ability to fold [13]. As the name denotes, the expression of HSPs were firstly demonstrated as a response heat shock but were demonstrated also to be induced by other stresses such as, ischemia, hypoxia and heavy metals [14-17].

HSPs manipulation was reported to be involved in cell death signaling and affect the fate of cells in neurological injury and disease states [18].

Melatonin is the main secretion of pineal gland and possesses antioxidant and anti-inflammatory actions [19]. The therapeutic and prophylactic effects of melatonin was previously investigated on heatstroke-induced multiple organ dysfunction syndrome in rats under general anesthesia $[20,21]$.

Hence, the aim of the present work was to investigate the protective effect of melatonin on cerebral cortex against heat stress-induced histological and HSP60 immunoexpression alterations and on serum oxidative status in adult male albino rats.

\section{Material and methods}

Forty adult male albino rats ( 6 months old $\& 240 \mathrm{gm} \pm 20$ body weight) were obtained from the Egyptian Organization for Biological Products and Vaccines. Rats were kept in individual polyethylene cages with stainless-steel tops at the Animal House, Faculty of Medicine, Zagazig University. Before the start of thermal experiments, rats were subjected to controlled conditions of ambient temperature $\left(22-26^{\circ} \mathrm{C}\right)$ and relative humidity of $50 \%-55 \%$ and illumination ( $12 \mathrm{~h}$ - light/dark), and allowed free access to normal rat chow diet and water ad libitum. The experiment was carried out in compliance with the "Guide of the Care and Use of Laboratory Animals" [22]. Experimental protocols were approved by the ethical committee of the faculty of medicine, Zagazig University. One week after acclimatization rats were randomly divided into three equal groups.
Group I (control group): Included twenty rats were divided into 2 equal subgroups, ten rats each: Subgroup la (Negative control) and. Subgroup lb (melatonin): as rats of subgroup la and received melatonin intraperitoneally at a dose of $10 \mathrm{mg} /$ $\mathrm{kg} /$ body weight [23].

Group II (heat stressed group): Included ten rats exposed to whole body heating $\left(\mathrm{WBH} ; 41^{\circ} \mathrm{C}\right.$ and relative humidity $50 \%-55 \%$ ) for $1 \mathrm{~h}$ daily in an environment-controlled chamber for 3 days. Core temperatures were measured every 1 minute with a copper constant thermocouple inserted into the rectum and connected to a thermometer (HR1300; Yokogawa, Tokyo, Japan). Every day, the heat-stressed rats were returned to the normal room temperature $\left(22-26^{\circ} \mathrm{C}\right)$ and were properly fed and hydrated after the end of the heat exposure [24].

Group III (heat stressed with melatonin treatment group): Included ten rats exposed to whole body heating as rats of group II but with simultaneous treatment with melatonin intraperitoneally at a dose of $10 \mathrm{mg} / \mathrm{kg} /$ body weight [23]. Melatonin was purchased from Sigma (St Louis, MO, USA).

\section{Histological study}

At the end of the experiments, the animals were sacrificed by decapitation under mild anesthesia (anesthetic ether) and the skulls were carefully opened. To prepare paraffin blocks, brains were immediately placed in $10 \%$ buffered formalin. After $10 \mathrm{~min}$, when the cerebral tissue was hardened to avoid soft tissue dissipation, $1 \mathrm{~cm}^{3}$ specimens were taken from the cerebral cortices of the anterior lobe above the primary fissure. The specimens were fixed in $10 \%$ buffered formalin for $24 \mathrm{~h}$ and processed to prepare $5 \mu \mathrm{m}$ sections stained with hematoxylin and eosin (H\&E) stain for histological study [25]. For immunohistochemical study, the deparaffinized $5 \mu \mathrm{m}$ paraffin sections on charged slides were used for localization of heat shock protein (HSP) using avidin-biotin-complex (ABC) immunoperoxidase technique. The sections were incubated in hydrogen peroxide for 10 min to block the endogenous peroxidase then incubated with the primary anti-HSP60 antibody at 1:100 dilutions for $20 \mathrm{~min}$ at room temperature. The primary antibody used was a mouse monoclonal antibody HSP60 Ab-1 obtained from Lab Vision Corporation, Medico Co., Egypt (Cat. \#MS-120-P0, Clone LK1). Then the slides were washed with phosphate buffer then incubated with the secondary anti-mouse antibodies universal kits obtained from Zymed Corporation. Staining was completed by incubation with substrate chromogen DAB (3,3' Diaminobenzidine) for 5-10 min which resulted in brown-colored precipitate at the antigen sites and Mayer's Hematoxylin was used as a counter stain. Positive control was MAD109 cells in breast cancer. For negative controls, incubation was carried out with the omission of the primary antiserum [26].

Sections were viewed using an Olympus microscope (C5060-AUD, 5H01155 JAPAN) and images were captured 
by a digital camera (Canon Power Shot A620, England, UK).

\section{Biochemical study}

Blood samples were obtained by repeated needle puncture of the tail tip veins and put into plain sample bottle for lipid peroxidation and antioxidant analysis. The blood sample was allowed to clot and centrifuged at $4000 \mathrm{~g}$ for 10 minutes and the serum obtained was used for the estimation of serum malondialdehyde (MDA), glutathione peroxidase (GSH-Px) and TNF-a.

Malondialdehyde (MDA) levels in samples were measured using the thiobarbituric acid reaction method [27]. The principle of the method based on that MDA can react with thiobarbituric acid (TBA) and give pink-colored trimethine complex with a maximum absorption at $530-532 \mathrm{~nm}$. The samples were analysed by a spectrophotometer. To measure MDA level, $1.25 \mathrm{ml}$ of $20 \%$ trichloroacetic acid (TCA) was added to $250 \mu \mathrm{L}$ serum and shaken in centrifuge tube. To the previous mixture, $500 \mu \mathrm{L}$ of TBA was added, mixed and placed in boiling water for $10 \mathrm{~min}$. After cooling, $2 \mathrm{ml}$ of $\mathrm{n}$-butanol was added to the mixture, shaken and centrifuged at $3000 \mathrm{rpm}$ for $10 \mathrm{~min}$. Finally, supernatant resultant n-butyl-alcohol layer was separated and the optical density was measured at $535 \mathrm{~nm}$ by comparing the absorption to the standard curve of MDA equivalents generated by bisdimethylacetal. The values of MDA were expressed as $\mathrm{nmol} / \mathrm{L}$.

Serum TNF-a in individual study groups were determined in serum using ELISA [28]. Determinations were performed according to the manufacturer's instructions using commercially available kits (Biosource International, Camarillo, CA, USA). Serum samples were added to a 96-well microplate coated with monoclonal antibodies against TNF- $a$. During incubation at room temperature, TNF- a were immobilised by solid-phase-bound antibodies. Subsequently, the unbound factors were rinsed away and the conjugate bound to a specific enzyme was added to the wells. The wells were rinsed to remove the unbound conjugate part. In order to determine the amount of proteins in the sample, a substrate solution is added to the wells. The enzyme reaction yields a blue product that turns yellow when the Stop Solution is added. The intensity of the color measured at $450 \mathrm{~nm}$ is in proportion to the amount of TNF-a bound in the initial step. The sample values are then read off the standard curve. Concentrations were expressed in $\mathrm{pg} / \mathrm{ml}$.

Glutathione peroxidase (GSH-Px) activity was measured by NADPH oxidation, using a coupled reaction system consisting of glutathione, glutathione reductase, and cumenehydroperoxide [29]. $100 \mu \mathrm{L}$ of serum was incubated for 5 minutes with $1.55 \mathrm{ml}$ stock solution (prepared in $50 \mathrm{mMTris}$ buffer, $\mathrm{pH} 7.6$ with $0.1 \mathrm{mM}$ EDTA) containing $0.25 \mathrm{mM} \mathrm{GSH}, 0.12 \mathrm{mM}$ NADPH and 1 unit glutathione reductase. The reaction was initiated by adding $50 \mu \mathrm{L}$ of cumenehydroperoxide $(1 \mathrm{mg} / \mathrm{ml})$, and the rate of disappearance of NADPH with time was determined spectrophotometerically by monitoring absorbance at 340 $\mathrm{nm}$. One unit of enzyme activity is defined as the amount of enzyme that transforms $1 \mu \mathrm{mol}$ of NADPH to NADP per minute.

\section{Morphometric study}

The image analyzer computer system Leica Qwin 500, (Cambridge, UK) in the image analyzing unit of the Pathology Department, Faculty of Dentist, Cairo University, Egypt was used. The number of apoptotic neurons was counted in H\&E stained sections. The number of HSP60 immunopositive cells was counted and the optical density of nuclear and cytoplasmic HSP60 immunoexpression was evaluated in anti-HSP60 immunostained sections. The measurements were in 10 consecutive fields i from each rat in randomly chosen five animals of each group at a magnification X400. They were measured using the color detect menu and in relation to a standard measuring frame.

\section{Statistical analysis}

Data for all groups were expressed as mean \pm standard deviation $(X \pm S D)$. The obtained data were analyzed by SPSS program version 15 (Chicago, USA; "http//WWW.SPSS.com"). Statistical analysis using one-way analysis of variance (ANOVA) test for comparison between different groups was conducted. The results were considered to be statistically significant, highly significant, and non-significant when the $P$ value was less than 0.05 , less than 0.001 , and more than 0.05 , respectively.

\section{Results}

The results of subgroups la and Ib were similar and did not show any variations, therefore, results of subgroup la were represented as the control group (I).

\section{Histological and immunohistochemical results}

Light microscopic examination of cerebral cortex of control group showed nerve cells with pale stained nuclei, neuropil and blood vessels surrounded by perivascular astrocyte foot process. Immunohistochemical localization of HSP60 showed weak cytoplasmic HSP60 immunoexpression of nerve cells (Figures 1A and 1B). After 3 days of heat exposure, nerve cells appeared with darkly stained pyknotic nuclei and surrounded by neuropil edema with presence of areas of subarachenoid hemorrhage and congested blood vessel. HSP60 immunoexpression was strong cytoplasmic in the nerve cells (Figures 2A-2C). In heat exposure + melatonin treatment, few nerve cells appeared with darkly stained pyknotic nuclei and few blood vessels were surrounded by swollen astrocytes processes. Some neurons revealed strong cytoplasmic HSP60 immunoexpression and others appeared with moderate nuclear immunoexpression (Figures 3A-3C).

\section{Morphometric results}

Statistical analysis the number of apoptotic cells showed significant increase in cerebral cortex of heat stressed group (II) when compared to both control group (I) and heat stressed 


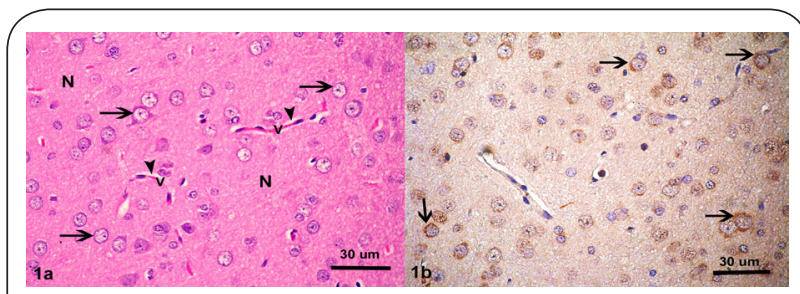

Figure 1. Photomicrographs of sections in cerebral cortex of control rats showing neuropil $(\mathrm{N})$ and nerve cells (thick arrows) with pale stained nuclei. Blood vessels (v) appear surrounded by perivascular astrocyte foot process (arrow heads) (a, H\&E X 400). Weak cytoplasmic HSP60 immunoexpression of nerve cells (arrows) is observed (b, Anti-HSP60 X 400).
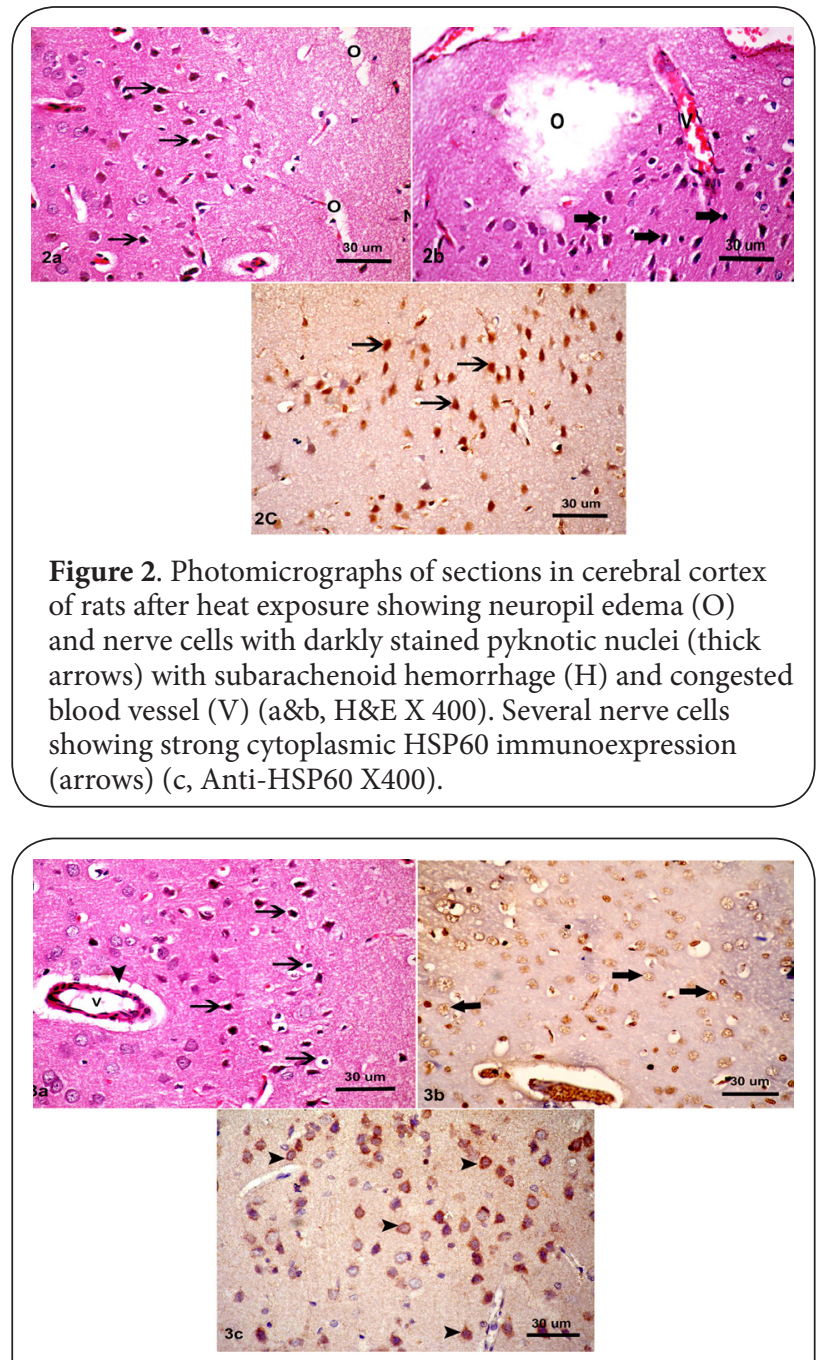

Figure 3. Photomicrographs of sections in cerebral cortex of rats after heat exposure with melatonin treatment showing few nerve cells with darkly stained pyknotic nuclei (arrows) and a blood vessel (v) surrounded by swollen astrocytes processes (arrow heads) (a, H\&E X 400). Some neurons revealed moderate nuclear HSP60 immunoexpressions (thick arrows) and others appear with strong cytoplasmic immunoexpression (arrowheads) (b\&c, Anti-HSP60 X400). with melatonin treatment (III). The number of HSP60 immunopositive cells and the optical density of nuclear HSP60 immunoexpression showed significant increase in cerebral cortex of heat stressed with melatonin treatment group (III) when compared with that of both control (I) and heat stressed group (II). The optical density of ctoplasmic HSP60 immunoexpression was significantly increased in cerebral cortex of heat stressed group (II) when compared with that of both control group (I) and heat stressed with melatonin treatment group (III) (Table 1).

\section{Biochemical results}

Serum MDA and TNF-a showed significant increase in heat stressed group II and non significant increase in heat stressed with melatonin group III when compared with control group I. Serum GPx showed significant decrease in heat stressed group II and non significant increase in heat stressed with melatonin group III when compared with control group I (Table 2).

\section{Discussion}

Hyperthermia was reported to have harmful effects on neuronal structure and function [30]. Neurons, as postmitotic cells, are more vulnerable to the toxic effects of the misfolded and /or aggregated proteins [31]. In the present study, the rats of heat stress group were exposed to whole body heating of $41^{\circ} \mathrm{C}$ for $1 \mathrm{~h}$ daily. The animal housing guidelines recommended maintaining rats between $22-26^{\circ} \mathrm{C}$ for their normal physiology and development [32].

\section{Degenerative changes with heat exposure}

Neuropil edema, congested blood vessels and subarachnoid hemorrhage were observed after 3 days of hyperthermia in the present work. That could be explained by previous investigators who observed that hyperthermia above $40^{\circ} \mathrm{C}$, in humans, led to increase in cerebral blood flow velocity of about 2 fold and that may increase vascular engorgement with cerebral edema [33]. Moreover, hyperthermia was reported to disturb the cerebral blood flow autoregulation mechanisms leading to disruption of the blood brain barrier integrity and exposing the brain to edema [34].

The present work showed that heat stress led to degenerative changes in cerebral cortex with concomitant significant increase in serum oxidative stress markers MDA and TNF- $a$ and decrease in antioxidant marker GPx. Similar findings were observed after heat stress in neural tissue of mice hypothalamus [35] and in cultured neurons of rat in the form of neuronal apoptosis with shrunken fragmented nuclei with caspase-3 activation and release of cytochrome $c$ [36]. These results are in consistence with previous investigators who reported that heat stress could stimulate programmed cell death of nerve cells leading to brain damage and also exacerbate tissue damage caused by brain trauma, stroke or neurotoxic drugs [37-39].

The cell death due to heat stress could be explained by 
Table 1. Mean values $( \pm \mathrm{SD})$ of the number of apoptotic cells and HSP60 immunopositive cells (cells per $\mathrm{mm} 2$ ) and the optical density of cytoplasmic and nuclear HSP60 immunoexpression among the studied groups.

\begin{tabular}{llll}
\hline & $\begin{array}{l}\text { Group I } \\
\text { (Control) }\end{array}$ & $\begin{array}{l}\text { Group II } \\
\text { (Heat stressed) }\end{array}$ & $\begin{array}{l}\text { Group III } \\
\text { (Heat stressed + Melatonin) }\end{array}$ \\
\hline Number of apoptotic cells & $10 \pm 2.2$ & $432 \pm 55^{*}$ & $121 \pm 20.1^{*}$ \\
Number of HSP60 immunopositive cells & $141 \pm 12$ & $211 \pm 17$ & $242 \pm 21^{\#}$ \\
OD of nuclear HSP60 immunoexpression & $1.3 \pm 0.6$ & $1.9 \pm 0.2$ & $9.1 \pm 1.8^{*}$ \\
OD of cytoplasmic HSP60 immunoexpression & $8.2 \pm 3.1$ & $18.6 \pm 4.2^{*}$ & $10.3 \pm 2.4$ \\
\hline
\end{tabular}

OD: optical density; ${ }^{*}$ : Significant difference with group I and III $(\mathrm{P}<0.05)$; \#: significant difference with group II $(\mathrm{P}<0.05) ; \pm \mathrm{SD}$ : standard deviation.

Table 2. Mean values $( \pm S D)$ of MDA, TNF- $\alpha$ and GPx in serum among the studied groups.

\begin{tabular}{llll}
\hline & $\begin{array}{l}\text { Group I } \\
\text { (Control) }\end{array}$ & $\begin{array}{l}\text { Group II } \\
\text { (Heat stressed) }\end{array}$ & $\begin{array}{l}\text { Group III } \\
\text { (Heat stressed + Melatonin) }\end{array}$ \\
\hline MDA $(\mathrm{nmol} / \mathrm{L})$ & $24.5 \pm 2.4$ & $39 \pm 4.4^{*}$ & $26.3 \pm 3.2$ \\
$\mathrm{TNF}-\alpha(\mathrm{pg} / \mathrm{ml})$ & $23.30 \pm 2.6$ & $72.96 \pm 5.6^{*}$ & $27.2 \pm 3.8$ \\
$\mathrm{GPx}(\mathrm{IU} / \mathrm{ml})$ & $2534.9 \pm 71.4$ & $1278.1 \pm 51.4^{*}$ & $2712 \pm 73.3$ \\
\hline
\end{tabular}

*: Significant difference with group I $(\mathrm{P}<0.05) ; \pm$ SD: standard deviation.

previous investigators who observed that hyperthermia led to impairment of oxidative phosphorylation through the increase in mitochondrial inner membrane permeability with disruption of energy production [40]. Also, exposure of rats to hyperthermia more than $42^{\circ} \mathrm{C}$ was reported to induce mitochondrial dysfunction in cardiomyocytes [41]. In addition, Riezman suggested that the loss of cell viability, due to heat stress, may be attributed to accumulation of denatured or aggregated proteins [42].

\section{Melatonin ameliorates the degenerative changes}

In the present work, simultaneous melatonin treatment with heat stress ameliorated the cerebral cortex degenerative changes with significant decrease in serum oxidative stress markers MDA and TNF- $a$ and increases in antioxidant marker GPx. That was attributed to the reported antioxidant and antiinflammatory and axonal regrowth-promoting effects of melatonin $[24,43]$. Previous investigators concluded similar effect of melatonin in decreasing lipid peroxidation markers in brain tissue after thyrotoxicosis in rats [44]. The easy of melatonin crossing through the blood-brain barrier could explain this effectiveness of melatonin in protecting the central nervous system from oxidative damage [45]. Melatonin was suggested as a therapeutic agent against brain edema as it enhances blood brain barrier integrity [46]. Moreover, melatonin was reported to prevent retinal neovascularization, preserved neuroglial function, and attenuated inflammation in the retina of oxygen-induced retinopathy mice via inhibition of vascular endothelial growth factor pathway [47].

Sinha and his colleagues suggested that melatonin neuroprotective effect in hypoxic ischemic brain injury in mouse is mediated by the inhibition of mitochondrial cell death, the restoration of melatonin receptor $1 \mathrm{~A}$, and the suppression of astrocytes and microglia [48].

Melatonin acts as a potent nitric oxide scavenger, inhibitor, and/or down regulator of neuronal nitric oxide synthesis and as a mitochondrial metabolism modulator [49]. Melatonin protected against mitochondrial reactive oxygen speciesmediated apoptosis in astrocytes [50].

\section{HSP60 immunoexpression after heat exposure}

In the present work, exposure to heat led to increase in the immunoexpression for HSP60. Similarly, increased intracellular HSP70 was observed in cultured astrocytes after heat stress [51] and in rat cerebral cortex due to ischemia after occlusion of the middle cerebral artery [52]. Similarly, Dangi and his colleagues observed increased immunocytochemical HSPs localization both in nucleus and cytoplasm of peripheral blood mononuclear cell with heat stress and suggesting a possible role of HSPs on heat stress amelioration [53].

The protective role of increased cellular HSPs after stresses was reported by several previous studies. HSP70 expression was reported to protect the cells against radiation [54], apoptosis, reactive oxygen species, endotoxins and ischemia [55]. Also, after transpupillary laser irradiation, HSP70 expression was observed by Kim and his colleagues to be increased in optic nerve head and they considered that as a natural cytoprotection against stress [56]. The increased HSPs detected after sublethal heat shock in several organs in rats $[\mathbf{5 7}, \mathbf{5 8}]$ and in hypothalamus of mice [35], could suggest HSPs as a protector against circulatory shock caused by cerebral ischemia and oxidative damage. Previous investigators suggested that 
increased HSPs, after nerve injury, could protect neurons from apoptotic cell death [59]. Also, it was observed that heat stress led to increased expression of HSPs in the cells of intestinal mucosa that was suggested to improve antioxidant capacity to protect cells from injury [60]. On the other hand, cells deficient in HSPs were reported to be more sensitive to stress with inability to develop thermotolerance [61].

The relation between heat stress and HSPs could be explained by previous investigators who reported that heat shock, as an acute stress condition, cause increase in synthesis of unfolded proteins with abnormal protein aggregation $[31,62]$. Moreover, thermal stress was reported to result in unfolding of already synthesized proteins but the binding of HSPs to these proteins refolded them and prevented their aggregation [63]. Hence, this increase in HSP60 immunoexpression in present study due to heat stress could be explained by previous investigators who reported that under normal conditions, cellular HSPs levels could match all the level of synthesized protein and mediate their proper folding but under stress, some HSPs expression increased and the newly formed HSPs act as chaperone that bind to denatured proteins trying to restore protein homeostasis and prevent their aggregation $[11,64]$. The balance between HSPs capacity and the misfolded proteins formation was suggested to be an effective therapy [63]. Barreto and his colleagues observed that HSP72 overexpression after cerebral ischemia was associated with reduced glial fibrillar acidic proterin (GFAP) density and hence, suggested modulating effect of HSPs on astrocytes [65]. In addition, overexpression of HSPs was reported to protect brain against ischemia by anti-inflammatory mechanism, through inhibition of innate immune response and several drugs nowadays has been used to induce cellular HSPs through increasing its transcriptional level [66]. Moreover, HSPs were reported to affect the function of mitochondria in the cells of skeletal muscle, adipose tissue and pancreas that suggesting the use of HSPs in diabetes mellitus treatment [67]. On the other hand, enhanced HSPs expression and its extracellular release was reported to act as danger signal in atherosclerosis due to stimulation of immune reactions [17] and cancer cells was documented to be dependent on HSPs and so, HSPs inhibitors could be used as anticancer drugs $[63,68]$.

\section{HSP60 localization after heat stress and modulatory effect with melatonin treatment}

In the present work, HSP60 immunoexpression in neurons was weak cytoplasmic in control group then was translocated to be strong cytoplasmic in heat stressed group then moderate nuclear and strong cytoplasmic in heat stress with melatonin treatment group. Similarly, HSPs were reported by previous investigators to be cytoplasmic proteins then translocated to the nucleus under cellular stress and growth [69]. That could be explained by previous investigators who reported that normally, HSPs are inactive and bound to heat shock factor
(HSF) in the cytoplasm and under heat stress, HSF separate from HSPs and enter the nucleus to bind with heat shock elements (HSEs) in the HSP gene promoter region $[\mathbf{5 7 , 7 0 ]}$. Then, HSP mRNA is transcribed and leaves the nucleus to the cytoplasm where new HSPs are synthesized with increased cytoplasmic expression. Also, acute exposure of astrocytes to ethanol was observed to stimulate translocation of HSF into the nucleus, to start the activation of HSPs transcription with HSPs accumulation in the cytoplasm [71].

In the present work, melatonin led to significant increase in the nuclear HSP60 immunoexpression in preserved nerve cells after heat stress. That is in consistence with Shi and his colleagues who suggested direct link between melatonin and thermotolerance in Arabidopsis [72]. Also, it was suggested that melatonin prevent the development of pancreatic inflammation after acute pancreatitis through increasing production of HSP60 [73].

\section{The relation between HSP60 immunoexpression and degenerative changes}

The increased nuclear immunoexpression of HSP60 in the present study was associated with decrease in the number of apoptotic cells with melatonin therapy. Similarly, dramatic increase in nuclear HSP72 was observed in cultured HeLa cells after hyperthermia that was suggested to protect the nucleus against apoptosis [74]. Moreover, they added that the flavonoids such as quercetin are apoptotic inducer through suppression of both HSP72 expression and migration to the nucleus. Also, it was concluded that cytoplasmic HSP27 expression inhibited nuclear apoptosis [75] which was reported to be through binding with cytochrome $c$ and procaspase-3 [76]. In cultured cortical neurons and astrocytes of rat, HSPs was induced 24 hours after heat stress with early translocation of it into the nucleus of astrocytes but that was delayed in neurons. Hence, it was suggested that the more susceptibility of neurons to injury may be attributed to this delay in HSP70 translocation [77]. Previous investigators observed that oxidative stress caused by several environmental stresses lead to translocation of cytoplasmic HSP to the nucleus to protect the cell from damage $[15,78]$. Moreover, nuclear HSP60 localization was reported to be crucial for stem cells to escape from senescence and improve self-renewal and ability to differentiate into neurons [79]. In addition, Zhang and his colleagues suggested that the regulation of HSP60 production is a potential therapeutic option for the treatment of neurodegenerative disorders [80].

\section{Conclusion}

Melatonin ameliorates heat exposure induced degenerative changes in cerebral cortex of adult male albino rats most probably through antioxidant effect with modulation in HSP60 immunolocalization. Hence, more attention should be thrown to melatonin and HSPs modulators as a protective 


\section{therapy against heat stress.}

\section{Competing interests}

The authors declare that they have no competing interests.

Authors' contributions
\begin{tabular}{|l|c|c|}
\hline Authors' contributions & HEH & AAF \\
\hline Research concept and design & $\checkmark$ & $\checkmark$ \\
\hline Collection and/or assembly of data & $\checkmark$ & -- \\
\hline Data analysis and interpretation & $\checkmark$ & $\checkmark$ \\
\hline Writing the article & $\checkmark$ & $\checkmark$ \\
\hline Critical revision of the article & $\checkmark$ & -- \\
\hline Final approval of article & $\checkmark$ & $\checkmark$ \\
\hline Statistical analysis & -- & $\checkmark$ \\
\hline
\end{tabular}

Publication history

EIC: Gaetano Giuseppe Magro, University of Catania, Italy.

Received: 04-April-2018 Final Revised: 23-April-2018

Accepted: 30-April-2018 Published: 12-May-2018

\section{References}

1. White MG, Saleh O, Nonner D, Barrett EF, Moraes CT and Barrett JN. Mitochondrial dysfunction induced by heat stress in cultured rat CNS neurons. J Neurophysiol. 2012; 108:2203-14. | Article | PubMed Abstract I PubMedFullText

2. Lundgren K, Kuklane K, Gao C and Holmer I. Effects of heat stress on working populations when facing climate change. Ind Health. 2013; 51:3-15. | Article | PubMed

3. Shen $\mathrm{KH}$, Lin $\mathrm{CH}$, Chang $\mathrm{HK}$, Chen WC and Chen SH. Premarin can act via estrogen receptors to rescue mice from heatstroke-induced lethality Shock. 2008; 30:668-74. I Article I PubMed

4. Leon LR and Helwig BG. Heat stroke: role of the systemic inflammatory response. J Appl Physiol (1985). 2010; 109:1980-8. | Article I PubMed

5. Pearce SC, Mani V, Boddicker RL, Johnson JS, Weber TE, Ross JW, Rhoads RP, Baumgard LH and Gabler NK. Heat stress reduces intestinal barrier integrity and favors intestinal glucose transport in growing pigs. PLOS One. 2013; 8:e70215. | Article | PubMed Abstract | PubMedFullText

6. Harikai N, Tomogane K, Miyamoto M, Shimada K, Onodera S and Tashiro $\mathrm{S}$. Dynamic responses to acute heat stress between 34 degrees $\mathrm{C}$ and 38.5 degrees $C$, and characteristics of heat stress response in mice. Biol Pharm Bull. 2003; 26:701-8. I Article | PubMed

7. Brownstein AJ, Ganesan S, Summers CM, Pearce S, Hale BJ, Ross JW, Gabler N, Seibert JT, Rhoads RP, Baumgard LH and Selsby JT. Heat stress causes dysfunctional autophagy in oxidative skeletal muscle. Physiol Rep. 2017; 5. I Article | PubMed Abstract | PubMedFullText

8. Kerner MJ, Naylor DJ, Ishihama Y, Maier T, Chang HC, Stines AP, Georgopoulos C, Frishman D, Hayer-Hartl M, Mann M and Hartl FU. Proteome-wide analysis of chaperonin-dependent protein folding in Escherichia coli. Cell. 2005; 122:209-20. | Article | PubMed

9. Becker J and Craig EA. Heat-shock proteins as molecular chaperones. Eur J Biochem. 1994; 219:11-23. | Article | PubMed

10. Hartl FU and Hayer-Hartl M. Converging concepts of protein folding in vitro and in vivo. Nat Struct Mol Biol. 2009; 16:574-81. I Article | PubMed

11. Kakkar V, Meister-Broekema M, Minoia M, Carra S and Kampinga HH. Barcoding heat shock proteins to human diseases: looking beyond the heat shock response. Dis Model Mech. 2014; 7:421-34. I Article | PubMed Abstract | PubMedFullText

12. Morales AV, Hadjiargyrou M, Diaz B, Hernandez-Sanchez C, de Pablo $F$ and de la Rosa EJ. Heat shock proteins in retinal neurogenesis: identification of the PM1 antigen as the chick Hsc70 and its expression in comparison to that of other chaperones. Eur J Neurosci. 1998;
10:3237-45. | Article | PubMed

13. Maisnier-Patin S, Roth JR, Fredriksson A, Nystrom T, Berg OG and Andersson DI. Genomic buffering mitigates the effects of deleterious mutations in bacteria. Nat Genet. 2005; 37:1376-9. | Article | PubMed w

14. Milkman R. Temperature effects on day old Drosophila pupae. J Gen Physiol. 1962; 45:777-99. | Article | PubMed Abstract | PubMedFullText

15. Tang D, Kang R, Xiao W, Jiang L, Liu M, Shi Y, Wang K, Wang $H$ and Xiao $\mathrm{X}$. Nuclear heat shock protein $\mathbf{7 2}$ as a negative regulator of oxidative stress (hydrogen peroxide)-induced HMGB1 cytoplasmic translocation and release. J Immunol. 2007; 178:7376-84. I Article I PubMed Abstract | PubMedFullText

16. Tokuriki $\mathrm{N}$ and Tawfik DS. Chaperonin overexpression promotes genetic variation and enzyme evolution. Nature. 2009; 459:668-73. | Article | PubMed

17. Grundtman C, Kreutmayer SB, Almanzar G, Wick MC and Wick G. Heat shock protein 60 and immune inflammatory responses in atherosclerosis. Arterioscler Thromb Vasc Biol. 2011; 31:960-8. | Article | PubMed Abstract | PubMedFullText

18. Stetler RA, Gan Y, Zhang W, Liou AK, Gao Y, Cao G and Chen J. Heat shock proteins: cellular and molecular mechanisms in the central nervous system. Prog Neurobiol. 2010; 92:184-211. | Article I PubMed Abstract | PubMedFullText

19. Galano A, Tan DX and Reiter RJ. Melatonin as a natural ally against oxidative stress: a physicochemical examination. J Pineal Res. 2011; 51:1-16. | Article | PubMed

20. Lin XJ, Mei GP, Liu J, Li YL, Zuo D, Liu SJ, Zhao TB and Lin MT. Therapeutic effects of melatonin on heatstroke-induced multiple organ dysfunction syndrome in rats. J Pineal Res. 2011; 50:436-44. I Article I PubMed

21. Wu WS, Chou MT, Chao CM, Chang CK, Lin MT and Chang CP. Melatonin reduces acute lung inflammation, edema, and hemorrhage in heatstroke rats. Acta Pharmacol Sin. 2012; 33:775-82. | Article | PubMed Abstract | PubMedFullText

22. Institute of Laboratory animals Resources. Commission on Life Science, National Research Council, Guide for the Care and Use of Laboratory Animals. National Academy Press, Washington, DC. 1996; 21-55. I Pdf

23. Czechowska G, Celinski K, Korolczuk A, Wojcicka G, Dudka J, Bojarska A and Reiter RJ. Protective effects of melatonin against thioacetamideinduced liver fibrosis in rats. J Physiol Pharmacol. 2015; 66:567-79. | Pdf I PubMed

24. Tian YF, Lin CH, Hsu SF and Lin MT. Melatonin improves outcomes of heatstroke in mice by reducing brain inflammation and oxidative damage and multiple organ dysfunction. Mediators Inflamm. 2013; 2013:349280. | Article | PubMed Abstract | PubMedFullText

25. Bancroft JD and Gamble M. Theory and Practice of Histological Techniques., 6 $^{\text {th }}$ ed. Churchill Livingstone, Scotland, London. 2008; $125-$ 138.

26. Kiernan JA. Histological and Histochemical Methods: Theory and Practice. Third edition, Arnold publisher, London, New York and New Delhi. 2001; 111-162.

27. Placer ZA, Cushman LL and Johnson BC. Estimation of product of lipid peroxidation (malonyl dialdehyde) in biochemical systems. Anal Biochem. 1966; 16:359-64. I Article I PubMed

28. Deshpande GG, Heidemann SM and Sarnaik AP. Heat stress is associated with decreased lactic acidemia in rat sepsis. Crit Care. 2000; 4:45-9. I Article | PubMed Abstract | PubMedFullText

29. Tappel AL. Glutathione peroxidase and hydroperoxides. Methods Enzymol. 1978; 52:506-13. | PubMed

30. White MG, Luca LE, Nonner D, Saleh O, Hu B, Barrett EF and Barrett JN. Cellular mechanisms of neuronal damage from hyperthermia. Prog Brain Res. 2007; 162:347-71. I Article | PubMed

31. Muchowski PJ and Wacker JL. Modulation of neurodegeneration by molecular chaperones. Nat Rev Neurosci. 2005; 6:11-22. | Article | PubMed

32. Le NP and Brown JW. Characterization of the Thermoneutral Zone of the Laboratory Rat. FASEBJ. 2008; 22. I Article 
33. Cremer OL and Kalkman CJ. Cerebral pathophysiology and clinical neurology of hyperthermia in humans. Prog Brain Res. 2007; 162:15369. | Article | PubMed

34. Walter EJ and Carraretto $M$. The neurological and cognitive consequences of hyperthermia. Crit Care. 2016; 20:199. | Article | PubMed Abstract | PubMedFullText

35. Chen ZC, Wu WS, Lin MT and Hsu CC. Protective effect of transgenic expression of porcine heat shock protein $\mathbf{7 0}$ on hypothalamic ischemic and oxidative damage in a mouse model of heatstroke. BMC Neurosci. 2009; 10:111. | Article | PubMed Abstract | PubMedFullText

36. White MG, Emery M, Nonner D and Barrett JN. Caspase activation contributes to delayed death of heat-stressed striatal neurons. $J$ Neurochem. 2003; 87:958-68. | Article | PubMed

37. Peng $\mathrm{H}$, Sola A, Moore J and Wen T. Caspase inhibition by cardiotrophin-1 prevents neuronal death in vivo and in vitro. J Neurosci Res. 2010; 88:1041-51. | Article | PubMed

38. Brown PL and Kiyatkin EA. Brain hyperthermia induced by MDMA (ecstasy): modulation by environmental conditions. Eur J Neurosci. 2004; 20:51-8. | Article | PubMed

39. White MG, Saleh O, Nonner D, Barrett EF, Moraes CT and Barrett JN. Mitochondrial dysfunction induced by heat stress in cultured rat CNS neurons. J Neurophysiol. 2012; 108:2203-14. | Article | PubMed Abstract I PubMedFullText

40. Qian L, Song X, Ren H, Gong J and Cheng S. Mitochondrial mechanism of heat stress-induced injury in rat cardiomyocyte. Cell Stress Chaperones. 2004; 9:281-93. | Article | PubMed Abstract | PubMedFullText

41. Zukiene R, Nauciene Z, Ciapaite J and Mildaziene V. Acute temperature resistance threshold in heart mitochondria: Febrile temperature activates function but exceeding it collapses the membrane barrier. Int $\mathrm{J}$ Hyperthermia. 2010; 26:56-66. I Article I PubMed

42. Riezman $\mathrm{H}$. Why do cells require heat shock proteins to survive heat stress? Cell Cycle. 2004; 3:61-3. | PubMed

43. Moretti R, Zanin A, Pansiot J, Spiri D, Manganozzi L, Kratzer I, Favero G, Vasiljevic A, Rinaldi VE, Pic I, Massano D, D’Agostino I, Baburamani A, La Rocca MA, Rodella LF, Rezzani R, Ek J, Strazielle N, Ghersi-Egea JF, Gressens $P$ and Titomanlio L. Melatonin reduces excitotoxic blood-brain barrier breakdown in neonatal rats. Neuroscience. 2015; 311:382-97. I Article I PubMed

44. Wiktorska JA, Lewinski A and Sewerynek E. Effects of different antioxidants on lipid peroxidation in brain homogenates, induced by L-thyroxine administration in rats. Neuro Endocrinol Lett. 2005; 26:704 8. I PubMed

45. Reiter RJ, Tan DX, Qi W, Manchester LC, Karbownik M and Calvo JR. Pharmacology and physiology of melatonin in the reduction of oxidative stress in vivo. Biol Signals Recept. 2000; 9:160-71. | Article | PubMed

46. Alluri H, Wilson RL, Anasooya Shaji C, Wiggins-Dohlvik K, Patel S, Liu Y, Peng X, Beeram MR, Davis ML, Huang JH and Tharakan B. Melatonin Preserves Blood-Brain Barrier Integrity and Permeability via Matrix Metalloproteinase-9 Inhibition. PLoS One. 2016; 11:e0154427. | Article | PubMed Abstract | PubMedFullText

47. Xu Y, Lu X, Hu Y, Yang B, Tsui CK, Yu S, Lu L and Liang X. Melatonin attenuated retinal neovascularization and neuroglial dysfunction by inhibition of HIF-1alpha-VEGF pathway in oxygen-induced retinopathy mice. J Pineal Res. 2018; 64:e12473. | Article | PubMed

48. Sinha B, Wu Q, Li W, Tu Y, Sirianni AC, Chen Y, Jiang J, Zhang X, Chen W, Zhou S, Reiter RJ, Manning SM, Patel NJ, Aziz-Sultan AM, Inder $T E$, Friedlander RM, Fu J and Wang X. Protection of melatonin in experimental models of newborn hypoxic-ischemic brain injury through MT1 receptor. J Pineal Res. 2018; 64. | Article | PubMed

49. Hardeland R, Backhaus $C$ and Fadavi A. Reactions of the NO redox forms $\mathrm{NO}+,{ }^{*} \mathrm{NO}$ and HNO (protonated NO-) with the melatonin metabolite N1-acetyl-5-methoxykynuramine. J Pineal Res. 2007; 43:382-8. | Article | PubMed

50. Jou MJ, Peng TI, Hsu LF, Jou SB, Reiter RJ, Yang CM, Chiao CC, Lin YF and Chen CC. Visualization of melatonin's multiple mitochondrial levels of protection against mitochondrial Ca2+-mediated permeability transition and beyond in rat brain astrocytes. J Pineal Res. 2010; 48:2038.

51. Taylor AR, Robinson MB, Gifondorwa DJ, Tytell M and Milligan CE. Regulation of heat shock protein 70 release in astrocytes: role of signaling kinases. Dev Neurobiol. 2007; 67:1815-29. I Article I PubMed

52. Tirapelli DP, Carlotti CG, Jr., Leite JP, Tirapelli LF and Colli BO. Expression of HSP70 in cerebral ischemia and neuroprotetive action of hypothermia and ketoprofen. Arq Neuropsiquiatr. 2010; 68:592-6. Article I PubMed

53. Dangi SS, Dangi SK, Chouhan VS, Verma MR, Kumar P, Singh G and Sarkar $M$. Modulatory effect of betaine on expression dynamics of HSPs during heat stress acclimation in goat (Capra hircus). Gene. 2016; 575:543-550. | Article | PubMed

54. Multhoff G, Pockley AG, Schmid TE and Schilling D. The role of heat shock protein $\mathbf{7 0}$ (Hsp70) in radiation-induced immunomodulation. Cancer Lett. 2015; 368:179-84. | Article | PubMed

55. Feder ME and Hofmann GE. Heat-shock proteins, molecular chaperones, and the stress response: evolutionary and ecological physiology. Annu Rev Physiol. 1999; 61:243-82. | Article | PubMed

56. Kim JM, Park KH, Kim YJ, Park HJ and Kim DM. Thermal injury induces heat shock protein in the optic nerve head in vivo. Invest Ophthalmol Vis Sci. 2006; 47:4888-94. I Article | PubMed

57. Wang JL, Ke DS and Lin MT. Heat shock pretreatment may protect against heatstroke-induced circulatory shock and cerebral ischemia by reducing oxidative stress and energy depletion. Shock. 2005; 23:161-7. | Article I PubMed

58. Giffard RG, Han RQ, Emery JF, Duan M and Pittet JF. Regulation of apoptotic and inflammatory cell signaling in cerebral ischemia: the complex roles of heat shock protein 70. Anesthesiology. 2008; 109:33948. | Article | PubMed Abstract | PubMedFullText

59. Kalmar B, Burnstock G, Vrbova G and Greensmith L. The effect of neonatal nerve injury on the expression of heat shock proteins in developing rat motoneurones. J Neurotrauma. 2002; 19:667-79. | Article I PubMed

60. Gu XH, Hao Y and Wang XL. Overexpression of heat shock protein 70 and its relationship to intestine under acute heat stress in broilers: 2 . Intestinal oxidative stress. Poult Sci. 2012; 91:790-9. | Article | PubMed

61. Zhang Y, Huang L, Zhang J, Moskophidis D and Mivechi NF. Targeted disruption of hsf1 leads to lack of thermotolerance and defines tissuespecific regulation for stress-inducible Hsp molecular chaperones. J Cell Biochem. 2002; 86:376-93. | Article | PubMed

62. Albanese V, Yam AY, Baughman J, Parnot C and Frydman J. Systems analyses reveal two chaperone networks with distinct functions in eukaryotic cells. Cell. 2006; 124:75-88. | Article I PubMed

63. Vabulas RM, Raychaudhuri S, Hayer-Hartl M and Hartl FU. Protein folding in the cytoplasm and the heat shock response. Cold Spring Harb Perspect Biol. 2010; 2:a004390. | Article | PubMed Abstract | PubMedFullText

64. Fulda S, Gorman AM, Hori O and Samali A. Cellular stress responses: cell survival and cell death. Int J Cell Biol. 2010; 2010:214074. | Article | PubMed Abstract | PubMedFullText

65. Barreto GE, White RE, Xu L, Palm CJ and Giffard RG. Effects of heat shock protein 72 (Hsp72) on evolution of astrocyte activation following stroke in the mouse. Exp Neurol. 2012; 238:284-96. | Article | PubMed Abstract | PubMedFullText

66. Kim JY, Yenari MA and Lee JE. Regulation of inflammatory transcription factors by heat shock protein $\mathbf{7 0}$ in primary cultured astrocytes exposed to oxygen-glucose deprivation. Neuroscience. 2015; 286:272-80. | Article I PubMed

67. Miova B, Dimitrovska M, Dinevska-Kjovkarovska S, Esplugues JV and Apostolova N. The Heat Stress Response and Diabetes: More Room for Mitochondrial Implication. Curr Pharm Des. 2016; 22:2619-39. | Article I PubMed

68. Neckers L. Heat shock protein 90: the cancer chaperone. J Biosci. 2007; 32:517-30. | Article | PubMed

69. Tabibzadeh S, Kong QF, Satyaswaroop PG and Babaknia A. Heat shock 
proteins in human endometrium throughout the menstrual cycle. Hum Reprod. 1996; 11:633-40. | PubMed

70. Kim N, Kim JY and Yenari MA. Anti-inflammatory properties and pharmacological induction of Hsp70 after brain injury. Inflammopharmacology. 2012; 20:177-85. | Article | PubMed

71. Pignataro L, Varodayan FP, Tannenholz LE, Protiva P and Harrison NL. Brief alcohol exposure alters transcription in astrocytes via the heat shock pathway. Brain Behav. 2013; 3:114-33. | Article | PubMed Abstract | PubMedFullText

72. Shi H, Tan DX, Reiter RJ, Ye T, Yang F and Chan Z. Melatonin induces class A1 heat-shock factors (HSFA1s) and their possible involvement of thermotolerance in Arabidopsis. J Pineal Res. 2015; 58:335-42. | Article | PubMed

73. Jaworek J, Szklarczyk J, Jaworek AK, Nawrot-Porabka K, Leja-Szpak A, Bonior J and Kot M. Protective effect of melatonin on acute pancreatitis. Int J Inflam. 2012; 2012:173675. | Article | PubMed Abstract | PubMedFullText

74. Jakubowicz-Gil J, Pawlikowska-Pawlega B, Piersiak T, Pawelec J and Gawron A. Quercetin suppresses heat shock-induced nuclear translocation of Hsp72. Folia Histochem Cytobiol. 2005; 43:123-8. I PubMed

75. Tsuchiya A, Tashiro E, Yoshida M and Imoto M. Involvement of nuclear accumulation of heat shock protein 27 in leptomycin B-induced apoptosis in HeLa cells. J Antibiot (Tokyo). 2005; 58:810-6. | Article | PubMed

76. Concannon CG, Orrenius S and Samali A. Hsp27 inhibits cytochrome c-mediated caspase activation by sequestering both pro-caspase-3 and cytochrome c. Gene Expr. 2001; 9:195-201. | PubMed

77. Nishimura RN and Dwyer BE. Evidence for different mechanisms of induction of HSP70i: a comparison of cultured rat cortical neurons with astrocytes. Brain Res Mol Brain Res. 1996; 36:227-39. | Article | PubMed

78. Ellis S, Killender M and Anderson RL. Heat-induced alterations in the localization of HSP72 and HSP73 as measured by indirect immunohistochemistry and immunogold electron microscopy. J Histochem Cytochem. 2000; 48:321-32. | Article | PubMed

79. Jang JH, Jung JS, Choi JI and Kang SK. Nuclear Ago2/HSP60 contributes to broad spectrum of hATSCs function via Oct4 regulation. Antioxid Redox Signal. 2012; 16:383-99. | Article | PubMed Abstract | PubMedFullText

80. Zhang R, Li Y, Hou X, Miao Z and Wang Y. Neuroprotective effect of heat shock protein 60 on matrine-suppressed microglial activation. Exp Ther Med. 2017; 14:1832-1836. | Article | PubMed Abstract | PubMedFullText

\section{Citation:}

Hashem HE and Fikry AA. A Modulation of heat shock protein immunolocalization in cerebral cortex by melatonin therapy in heat stressed rats.

J Histol Histopathol. 2018; 5:7.

http://dx.doi.org/10.7243/2055-091X-5-7 